\title{
Status of Hydrogen Peroxide Solution 10 V in Commercialized Samples de Menezes MN ${ }^{1}$, Kogawa $\mathrm{AC}^{2 *}$ and Salgado $\mathrm{HRN}^{2}$
}

${ }^{1}$ Pontifícia Universidade Católica do Rio Grande do Sul - PUCRS, Porto Alegre, Brazil

${ }^{2}$ School of Pharmaceutical Sciences School or Institute, São Paulo State University (UNESP), Campus Araraquara, São Paulo, Brazil

"Corresponding author: Ana Carolina Kogawa, Faculdade de Ciências Farmacêuticas de Araraquara, São Paulo State University (UNESP), Rodovia Araraquara-Jaú, km 1, CEP 14800-903, Araraquara, SP, Brazil, Tel: +55 163301 4681; Fax: +55 163301 6960; E-mail: ac_kogawa@yahoo.com.br

Received date: Sep 06, 2017; Accepted date: Oct 31, 2017; Published date: Nov 06, 2017

Copyright: (c) 2017 de Menezes MN, et al. This is an open-access article distributed under the terms of the Creative Commons Attribution License, which permits unrestricted use, distribution, and reproduction in any medium, provided the original author and source are credited.

\begin{abstract}
Hydrogen peroxide $\left(\mathrm{H}_{2} \mathrm{O}_{2}\right)$ is one of the most powerful oxidants used in many sectors. Analytical method such as titration by permanganometry is used to maintain the quality of products containing $\mathrm{H}_{2} \mathrm{O}_{2}$. Thus, the objective of this work was to evaluate commercial samples of $\mathrm{H}_{2} \mathrm{O}_{2} 10 \mathrm{~V}$ by permanganometry. A difference of almost 3 volumes was found in the analysis of the samples. These results can be real or assigned to the potassium permanganate solution, not automation of the results and/or instability of the $\mathrm{H}_{2} \mathrm{O}_{2}$ solutions, for example. The main issue is, in addition to alerting the consumers to adequate storage of $\mathrm{H}_{2} \mathrm{O}_{2}$ solutions, to alert the scientific community to the need for concomitant analysis methods for unstable products such as $\mathrm{H}_{2} \mathrm{O}_{2} 10 \mathrm{~V}$ solutions in order to avoid doubts on the results and make the manufacturers aware of these quality tests.
\end{abstract}

Keywords: Hydrogen peroxide; Titration by permanganometry; Potassium permanganate; Commercial samples

\section{Introduction}

Hydrogen peroxide $\left(\mathrm{H}_{2} \mathrm{O}_{2}\right)$ is one of the most powerful oxidants. Its use must be conducted safely and responsibly to avoid risk of burns and explosions [1].

The first commercialization of $\mathrm{H}_{2} \mathrm{O}_{2}$ dates back to 1800 and it is used in various sectors such as odor control, textile industries, medical area, food, pharmaceutical, water and sewage treatment [2-5].

Product quality must be monitored using analytical methods during the production process and before being released to the consumer market. They must meet the required specifications and follow good manufacturing practices [6].

Considering the importance of hydrogen peroxide on the global scene in the treatment of disinfecting wounds, partly because of its low cost and prompt availability compared to other antiseptics, the development of practical, economical and reliable analytical methods, which can be used in the quality control of this substance, is essential and highly relevant, seeking the therapeutic efficacy, patient's safety and also benefits for the pharmaceutical industries and compounding pharmacies.

Analytical methods are tools to evaluate the level of quality and suitability of products and materials. They include titration, spectrophotometry, chromatography, spectroscopy, among others.

Titration is a quantitative analysis method used to determine the concentration of many active pharmaceutical ingredients such as tetraphenylborate sodium, phenothiazine compounds, acetaminophen, captopril, ascorbic acid, albendozole, sparfloxacin, salbutamol sulfate, montelukast sodium, phenylephrine hydrochloride, candesartan cilexetil [7-17].

When titration is by oxide-reduction reactions there is the transfer of electrons from one species to another. The methods of oxidation- reduction volumetric are given specific names, depending on the substance used for the determinations [18].

Iodimetry=reactions involve the oxidation of iodide to iodine

Iodometry=reactions involve the reduction of iodine, reducing it from I0 to I-1

Permanganometry=reactions involve the reduction of manganese, reducing it from $\mathrm{Mn}^{+7}$ to $\mathrm{Mn}^{+2}$

In this context, the objective of this work was to evaluate commercial samples of $\mathrm{H}_{2} \mathrm{O}_{2} 10 \mathrm{~V}$ by permanganometry and discuss their status.

\section{Materials and Methods}

\section{Material}

Seven samples of $\mathrm{H}_{2} \mathrm{O}_{2} 10 \mathrm{~V}$, named $\mathrm{A}, \mathrm{B}, \mathrm{C}, \mathrm{D}, \mathrm{E}, \mathrm{F}$ and $\mathrm{G}$, commercially available from Araraquara city (Brazil) were used.

\section{Method}

The $\mathrm{H}_{2} \mathrm{O}_{2}$ analysis was performed by the permanganimetric method, in which the dosage is made directly in the sample, using titration of $0.1 \mathrm{M}$ potassium permanganate solution $\left(\mathrm{KMnO}_{4}\right)$ [19].

To determine the $\mathrm{H}_{2} \mathrm{O}_{2}$ concentration, $1 \mathrm{~mL}$ of $\mathrm{H}_{2} \mathrm{O}_{2}$ solution to be analyzed was added to conical flasks $\mathrm{A}$ to $\mathrm{G}$ adding $100 \mathrm{~mL}$ of purified water, to facilitate titration, and $5 \mathrm{~mL}$ of sulfuric acid solution $\left(\mathrm{H} 2 \mathrm{SO}_{4}\right)$ $1: 5$.

The contents of the Erlenmeyer flasks were titrated with $0.1015 \mathrm{M}$ $\mathrm{KMnO}_{4}$ solution, previously standardized with oxalic acid, until the color changes to the first permanent pink for 30 seconds. This procedure was performed 3 times for each sample.

Calculations for the determination of $\mathrm{H}_{2} \mathrm{O}_{2}$ content in the samples were based on the following Correspondences 
Page 2 of 3

Real volume of $\mathrm{KMnO}_{4}$ used in the analyzes considering the concentration of $\mathrm{KMnO}_{4} 0.1015 \mathrm{M}$

Consider the correspondence

$1 \mathrm{~mL} \mathrm{KMnO}_{4} 0.1 \mathrm{M}=1.701 \mathrm{mg} \mathrm{H} \mathrm{O}_{2}$

Consider the correspondence

$3 \%=3 \mathrm{~g} \mathrm{H}_{2} \mathrm{O}_{2}=100 \mathrm{~mL}$ sample

$3 \%=30 \mathrm{mg} \mathrm{H}_{2} \mathrm{O}_{2}=100 \mathrm{~mL}$ sample

Consider the correspondence

$34.02 \mathrm{~g} \mathrm{H}_{2} \mathrm{O}_{2}=16 \mathrm{~g} \mathrm{O}_{2}$

Consider the correspondence

$1 \mathrm{~mL} \mathrm{O}_{2}=0.0014301 \mathrm{~g} \mathrm{O}_{2}$

\section{Results}

The results of $\mathrm{H}_{2} \mathrm{O}_{2}$ determination in the seven analyzed samples are presented in Table 1 .

\begin{tabular}{|l|l|l|l|l|}
\hline $\begin{array}{l}\text { Sampl } \\
\text { e }\end{array}$ & $\begin{array}{l}\text { Volume of the } \mathbf{0 . 1} \mathbf{M ~ K M n O}_{4} \text { solution } \\
(\mathbf{m L})^{*}\end{array}$ & $\begin{array}{l}\text { RSD } \\
(\%)\end{array}$ & $\begin{array}{l}\text { Content } \\
(\%)\end{array}$ & $\begin{array}{l}\text { Content } \\
(\mathbf{V})\end{array}$ \\
\hline A & 17.56 & 0 & 2.99 & 9.82 \\
\hline B & 14.21 & 0.5 & 2.42 & 7.95 \\
\hline C & 17.46 & 0.41 & 2.97 & 9.77 \\
\hline D & 17.36 & 0 & 2.95 & 9.71 \\
\hline E & 16.24 & 0.44 & 2.76 & 9.08 \\
\hline F & 19.49 & 0.37 & 3.32 & 10.9 \\
\hline G & 14.31 & 0 & 2.43 & 8.01 \\
\hline *Volume (mL) of $0.1 \mathrm{M} \mathrm{KMnO}_{4}$ solutions - blank volume $(0.1 \mathrm{~mL})$ \\
\hline
\end{tabular}

Table 1: Titration results of $\mathrm{H}_{2} \mathrm{O}_{2} 10 \mathrm{~V}$ samples using $0.1 \mathrm{M} \mathrm{KMnO}_{4}$ solution.

\section{Discussion}

Quality Control is a very important step in the process of drug manufacturing, as it ensures its safety and efficacy. Thus, research on quality control of pharmaceutical products to identify the content of active and the study of physical and chemical characteristics of the drug are essential to ensure the quality of the final product.

Titration is a simple, low cost, accessible and precise method and there is no need of using reference standards. It is used in the analysis of diverse products by laboratories, research centres and even chemical-pharmaceutical industries. However, large amounts of sample (mg), non-automation of results, low specificity and substances with evaporative capacity can be disadvantages of titration [20-22].

In this context, titration stands out. It is a technique which can use low toxicity organic solvents and, although it is formally accepted for the identification of individual compounds, it also allows the quantitation of substances. In addition, the titration is a simple, fast, and economical method, making it a widely employed and extremely versatile technique [23-25].
The titration technique using $\mathrm{KMnO}_{4}$ is widely used in the analysis of $\mathrm{H}_{2} \mathrm{O}_{2}$ content. The permanganimetric method is used to determine $\mathrm{H}_{2} \mathrm{O}_{2}$ content using the oxide-reduction principle. Manganese is the oxidizing species and peroxide is the reducing agent.

As the most used unit of concentration for $\mathrm{H}_{2} \mathrm{O}_{2}$ is the volume it was necessary to calculate the volume concentration $(\mathrm{V})$ of the $\mathrm{H}_{2} \mathrm{O}_{2}$ solutions under analysis.

The tests of contents are necessary and important in the logistics of total quality and maintenance of the suitability of products in general. They also reveal the level of quality of process.

Seven samples of $\mathrm{H}_{2} \mathrm{O}_{2} 10 \mathrm{~V}$ were analyzed for their content by the permanganimetric method. Results ranged from 7.95 (sample B) to 10.90 (sample F), a difference of almost 3 volumes. This represents almost $30 \%$ of content in volumes.

However, a broader discussion about $\mathrm{KMnO}_{4}$ solution, not automation of the results and/or instability of the $\mathrm{H}_{2} \mathrm{O}_{2}$ solutions is valid.

It should be considered that potassium permanganate, although inexpensive, does not have characteristics of a primary standard, requiring prior standardization, as well as self-decomposition when exposed to light, reducing the concentration of the solution used as standard.

When the results are obtained based on the visualization of the color change, this can lead to differences and values that are significantly different from one analyst to another and the lack of automation of the results can impart false conclusions.

$\mathrm{H}_{2} \mathrm{O}_{2}$ decomposes very easily. This fact coupled with the suitability to the expiration date can lead manufacturers to work higher concentrations, aiming that until the end of the expiration date the concentration is that indicated in the label.

The association of methods for quality control of $\mathrm{H}_{2} \mathrm{O}_{2} 10 \mathrm{~V}$ can also be considered when there is doubt about a result or procedure [26].

Therefore, the standardization of some factors that can interfere with the analysis and consequently the results should be fixed. This ensures the reliability of methods and processes. It is part of the rigor of quality that each establishment prizes for its products [27].

The disclosure of results like these are important for the current quality awareness of $\mathrm{H}_{2} \mathrm{O}_{2} 10 \mathrm{~V}$ marketed widely and used by numerous people for various procedures ranging from disinfection to oral antiseptic.

This work is also a warning for any other product that contains $\mathrm{H}_{2} \mathrm{O}_{2}$ in its formula. The same parameters cited in this study should be considered and evaluated.

So, the main issue is, in addition to alerting the consumer to adequate storage of $\mathrm{H}_{2} \mathrm{O}_{2}$ solutions, to alert the scientific community to the need for concomitant analysis methods for unstable products such as $\mathrm{H}_{2} \mathrm{O}_{2} 10 \mathrm{~V}$ solutions in order to avoid doubts on the results and make the manufacturers aware of these quality tests.

\section{Conclusion}

The quality of $\mathrm{H}_{2} \mathrm{O}_{2} 10 \mathrm{~V}$ samples was evaluated and they showed almost $30 \%$ less content (in volumes). This academic research is an alert to the scientific community to the need for concomitant methods 
of analysis for this type of product and to make manufacturers aware of these quality tests. Moreover the importance of good storage to keep the quality of product and as well as the guaranty the stability of pharmaceutical products should be a concern.

\section{Acknowledgments}

The authors acknowledge CNPq (Brasília, Brazil), FAPESP (São Paulo, Brazil) and CAPES (São Paulo, Brazil) and Maria de Fátima Rodrigues for technical support.

\section{References}

1. Mattos IL, Shiraishi KA, Braz AD, Fernandes JR (2003) Peróxido de hidrogênio: importância e determinação. Química Nova 26: 373-380.

2. Baldry MGC (1983) The bactericidal, fungicidal and sporicidal properties of hydrogen peroxide and peracetic acid. J Applied Bacteriology 54: 417-423.

3. Campanella L, Roversi R, Sammartino MP, Tomassetti M (1998) Hydrogen peroxide determination in pharmaceutical formulations and cosmetics using a new catalase biosensor. J Pharmace and Biomed Ana 18: 105-116.

4. Gaikowski MP, Rach JJ, Ramsay RT (1999) Acute toxicity of hydrogen peroxide treatments to selected lifestages of cold, cool and warm water fish. Aquaculture 178: 191-207.

5. Maab F, Elias H, Wannowius KJ (1999) Kinetics of the oxidation of hydrogen sulfite by hydrogen peroxide in aqueous solution: ionic strength effects and temperature dependence. Atmospheric Environment 33: 4413-4419.

6. Bonfilio R, Emerick GL, Netto Júnior A, Salgado HRN (2010) Farmácia magistral: sua importância e seu perfil de qualidade. Revista Baiana de Saúde Pública 34: 653-664.

7. Diamandis EP, Christopoulos TK (1983) Potentiometric titration of pharmaceutical compounds in formulations with sodium tetraphenylborate. Analytica Chimica Acta 152: 281-284.

8. Golabi SM, Showkati-Shlwjnan M (1991) Potentiometric titration of phenothiazine compounds in chloroform and its use in pharmaceutical analysis. Talanta 38: 1253-1256.

9. Burgot G, Auffret F, Burgot JL (1997) Determination of acetaminophen by thermometric titrimetry. Analytica Chimica Acta 343: 125-128.

10. Marona HRN, Schapoval EES (2001) Development and validation of a nonaqueous titration with perchloric acid to determine sparfloxacin in tablets. European J Pharmaceutics and Biopharmaceutics 52: 227-229.

11. Paim APS, Almeida CMNV, Reis BF, Lapa RAS, Zagatto EAG, et al. (2002) Automatic potentiometric flow titration procedure for ascorbic acid determination in pharmaceutical formulations. J Pharmace and Biomed Anal 28: 1221-1225.

12. Basavaiah K, Prameela HC (2003) Three useful bromimetric methods for the determination of salbutamol sulfate. Analy and Bioanaly Chem 376: 879-883.
13. Basavaiah K, Prameela HC (2003) Use of an oxidation reaction for the quantitative determination of albendazole with chloramine-T and acid dyes. Analy Sci 19: 779-784.

14. Rahman N, Singh M, Hoda N (2005) Validation of simultaneous volumetric and spectrophotometric methods for the determination of captopril in pharmaceutical formulations. Farmaco 60: 569-574.

15. Aslan N, Erden PE, Canel E, Kilic E (2014) Development and validation of a potentiometric titration method for the determination of montelukast sodium in a pharmaceutical preparation and its protonation constant. Bulgarian Chemical Communications 46: 497-502.

16. Hasan SH, Othman NS, Surchi KM (2016) Determination of phenylephrine- $\mathrm{HCl}$ using conductometric titration method. Current Analytical Chemistry 12: 330-334.

17. Rele RV (2016) A validated non-aqueous potentiometric titration method for quantitative determination of candesartan cilexetilfrom pharmaceutical preparation. Inter J Chem Sci 14: 2696-2702.

18. Baccan N, Andrade JC, Godinho OES, Barone JS (2001) Química Analítica Quantitativa Elementar. Edgar Blücher, Third Edition. Brazilian Pharmacopeia (2010) ANVISA, Fifth Edition.

19. Brazilian Pharmacopeia. ANVISA, Fifth Edition 2010.

20. Shyichuk A, Ziółkowska D (2016) Determination of anionic surfactants by means of photometric titration with methylene blue dye. J Surfact Deterg 19: 425-429.

21. Yan Z, Zhang Z, Yu Y, Liu Z, Chen J (2016) Chemiluminescence determination of potassium bromate in flour based on flow injection analysis. Food Chem 190: 20-24.

22. Wang J, Liu X, Zhang J, Tong L, Zhang L (2016): Ultra micro liquid volume measurement system based on potentiometrie titration principle. Integrated Circuits and Microsystems, International Conference on IEEE.

23. Marona HRN, Schapoval EES (2001) Performance characteristics of bioassay, nonaqueous titration, UV-spectrophotometry and high performance liquid chromatographic determination of sparfloxacin in tablets. Brazilian J Pharmaceutical Sci 37: 171-175.

24. Marona HRN, Schapoval EES (2001) Spectrophotometric determination of sparfloxacin in pharmaceutical formulations using bromothymol blue. J Pharmac and Biomedical Analy 26: 501-504.

25. Marona HRN, Lopes CCGO, Cardoso SG (2003) Non-queous titration of gatifloxacin in pharmaceutical formulations using perchloric acid. Lat Americ J Pharm 22: 339-342.

26. Silva RAB, Montes RHO, Munoz RAA, Richter EM (2011) Determinação de peróxido de hidrogênio em antisséptico bucal usando um microdispositivo contendo partículas de azul da prússia. Química Novas 34: 987-991.

27. Kogawa AC, Salgado HRN (2017) Quality tools for a successful strategic management. Inter J Business Process Integration and Manag 8: 153-159. 